\title{
The Personal Documentary Funds of the Computer Technology Founders at the Polytechnic Museum
}

\author{
Marina Smolevitskaya \\ Scientific Researcher, Computer Collection Curator \\ Polytechnic Museum, Moscow, Russia \\ smol@polymus.ru, msmolevitskaya@yandex.ru
}

\begin{abstract}
The Polytechnic Museum has the Fund Collection "Electronic Digital Computing Machines". This Fund Collection is the only one of such variety and size in Russia. There are more eight hundred objects and over two thousands documentary, printed, graphic items today. All four generations of electronic digital computing machines are presented in the Museum. The main part of the Fund Collection is the developments of domestic scientist. The Museum created thirteen personal funds of Russian scientists who devoted their activity to computer science. There are biographical and official documents, scientific manuscripts and publications, descriptions of inventions and certificates of authorship for them, pictures at work and pictures from the family albums in these personal funds.
\end{abstract}

Keywords: Polytechnic Museum, collection, electronic digital computing machines, documents, pictures, papers, personal funds (unit-linked collections of documents), computer technology founders, Russian scientists.

\section{Introduction}

During the long years of its existence the Polytechnic Museum tries to limelight events and people which many generations are obliged. One of the most important areas of the museum activity is the restoration in memory of the wider community the contribution of Russian engineers and scientists. The museum has implemented the project "History of Russian engineering thought", including research, exposition, collection and educational activities. One of the goals of this project is to create a database about the heritage of outstanding Russian scientists. Research results are reflected in a series of publications "Problems of cultural heritage in the field of engineering." In accordance with this project, the museum hosts exhibitions and events devoted to outstanding creators of science and technology that helps maintain a high level of public recognition of our scientists and engineers.

In the Polytechnic Museum more than 20 years the scientific exposition Information Technology Department collected exhibits related to the biography, scientific and professional activities creators of computer technology in the Soviet Union and Russia. We opened 13 personal documentary funds on "Domestic science and 
engineering schools in the field of Computing and Informatics," which includes more than 800 authentic merchandise, documentaries, printed and graphic materials. The Polytechnic museum holds documentary funds academician S.A. Lebedev, academician V.M. Glushkov, corresponding member of the USSR Academy of Sciences I.S. Brook, his disciples - M.A. Kartsev and N.Ya. Matyuhin, talented creators B.I. Rameev and Yu.Ya. Bazilevskiyi, the developer of the only ternary computer in the world N.P. Brusentsov, mathematician S.N. Mergelyan, Director of the Moscow factory accounting machines V.S. Petrov, founders of the national school of cybernetics A.A. Lyapunov and V.A. Kitov, academician V.S.Burtsev. All of them have made an invaluable contribution to the domestic computers park and the further development of the domestic computing.

The personal documentary funds stored in the Polytechnic Museum are presented amply in the collection of articles "Problems of cultural heritage in the field of engineering". This article describes only the four personal documentary funds: S.A. Lebedev, V.S. Burtsev I.S. Brook and M.A. Kartsev. In the future, the author expects to perform a description of all personal funds of the founders of the domestic computing.

\section{Sergey Lebedev (1902 - 1974)}

Academician Sergey Lebedev - an outstanding scientist in electrical and power engineering and founder of the domestic computing [1].

The name of Lebedev related major events in the history of national computing:

- creation of the first national computers with stored program - Small Electronic Calculating Machine (SECM, in Russian - MESM) in 1951 and in 1953 - Large and in the future High-speed Electronic Calculating Machine (HsECM, in Russian - BESM);

- development of serial first-generation computer M -20 and then the secondgeneration computers, software-compatible with the M-20 ( 1958 , 1968);

- creation of high-performance general-purpose computer BESM-6 with a capacity of 1 million operations per second, a record in the second half of the 60 s to the computer park of the USSR and Europe (1966);

- issue powerful computer systems for the missile defense system (since 1956);

- organization of the engineering development school of universal high-performance machines - supercomputers.

Lebedev’s personal fund № 44 was created and updated through the cooperation of the museum with his daughter Natalia Lebedeva. Currently the fund has 44 storage units. These are Lebedev's manuscripts, rough drafts in notebooks and notepads, inventors' certificates, scientific works in electrical engineering, electric power and computer technology, photos of this scientist alongside his computers, photos from family albums.

The Polytechnic Museum has a number of documents related to the biography of Sergei Lebedev and his professional activities. There are handwritten memories of his sister famous artist Tatyana Mavrina, a decision to impose Lebedev Director of The Institute of Precision Mechanics and Computer Technology (IPM CT) of USSR 
Academia of Science and the ruling on his election as a academician in 1953, business cards, letters with colleagues. The museum store personal items belonging to Lebedev, and even has a bookshelf made him.

The name of Lebedev was awarded The Institute of Precision Mechanics and Computer Technology, which has a small museum.

Since 1994 Department of Informatics, Computer Science and Automation of Russian Academy of Sciences annually awards a prize named after Lebedev for the best work in the development of computing systems.

The international scientific community in the face of IEEE Computer Society recognized the merits Lebedev in 1996, giving him the title «Computer Pioneer».

In the same year Victor Glushkov and Alexei Lyapunov have got this title too.

Lebedev followers created their own scientific schools and groups.

\section{Vsevolod Burtsev (1927 - 2005)}

Academician Vsevolod Burcev was one of the Lebedev's disciples. Before graduating from the Moscow Energy Institute Bourtsev began his scientific and engineering activity under the guidance of S. Lebedev in IPM and CT [2]. Already at the stage of graduate design V.Burtsev became one of the leading developers of domestic electronic computing machines.

In 1952-1955 the result of joint work with the staff of Radio Research Institute was the creation of two specialized computer "Diana- 1" and "Diana- 2" for the automatic removal of data from radar and automatic tracking of air targets. Being responsible executor, V.Burtsev proposed the principle of selection and digitization of the radar signal. Based on this principle removal of target data from radar and putting them into the computer were done, an experiment for simultaneous tracking of multiple targets computing machine was successfully conducted. Further development of this work was the creation of a series of computers designed for ballistic missile defense (BMD).

The creators of the first missile defense system G.Kisunko, S.Lebedev and V.Burtsev received the Lenin Prize. The Notice of the Committee on Lenin Prizes in science and technology, which is also stored in the museum, evidenced.

Multicomputer complex of MDS (the eight machines 5E92b with automatic backup) has been tested in a real work in 1967. Later serial machines 5E92b became the basis of the country's missile defense system, ensured parity with the U.S. in the "cold war" and played an important political role in the conclusion of agreement to limit missile defense in 1972.

Thru selfless work V.Burtsev got the full confidence of academician Lebedev and became his assistant in creation of a reliable high-performance control and information systems for anti-missile and space monitoring centers.

In 1969-1972 V.Burtsev, as chief designer, created the first onboard computer of the third generation for ammunition combat anti-missile system C-300. Now these computers are on alert and are sold to other countries. 
When S.Lebedev died, V.Burtsev was appointed director IPMCT. Continuing the work of his teacher, Bourtsev put a lot of effort to create a family of super-computers "Elbrus" and further development works in the field of missile defense.

In 1973-1985 Vsevolod Bourtsev led the development of multiprocessor computing systems "Elbrus-1", "Elbrus-2", as the chief designer. The fundamental construction questions of universal processors with marginal productivity were resolved when creating complex "Elbrus".

In 1986-1993 the architecture of supercomputers based on the new, not the von Neumann principle, providing parallelized computational process at the hardware level was developed under the leadership V.Burtsev. This architecture uses the principles of optical data processing, has highly regular structure and achieves performance $10^{10}-10^{12} \mathrm{op} / \mathrm{s}$. The principal feature of the proposed architecture is automatic dynamic allocation of computing resources between the individual processes.

In 1992 V.S. Bourtsev was elected a member of the RAS in the Department of Informatics, Computing and Automation (specialty "Computing and Electronic Components").

Until his death (14.06.2005) academician V.Burtsev was the supervisor of fundamental research on the development of various unconventional architectural solutions HPC machines using new physical principles, as well as the system software to create data-processing systems at peak performance $10^{12}-10^{14} \mathrm{op} / \mathrm{s}$.

The fund of academician Vsevolod Burcev was formed by his wife Tamara Burtseva. This fund № 42 is one of the most rewarding interesting evidence of scientific thought and evidence of the practical implementation of his ideas in the domestic computers, which function reliably now.

Burtsev's documentary fund has over 70 storage units. There are manuscripts (rough notes in notebooks and notepads) diploma project dedicated random access memory of the famous BESM, inventors' certificates, the photos of scientist at work, the publishing of his scientific works.

The Polytechnic Museum has a number of documents related to the Burcev's biography and his professional activities. There are a brief autobiography, characterization of production and social activities, dated November 17, 1976, schedule debugging MVK "Elbrus-2", documents related to the preparation of receiving the title of academician of the Russian Academy of Sciences, correspondence and personal items belonging to V.Burtsev.

Bourtsev, like some of the other students of Moscow Energy Institute, participated in the preparation of preliminary design documentation of BESM. This material formed the basis of his diploma project, also stored in the documentary fund.

The materials associated with the creation of two specialized computer "Diana- 1" and "Diana- 2" and a series of computers designed for ballistic missile defense (BMD) are an extremely important part of the personal documentary fund of V.Burtsev in the Polytechnic Museum.

«With our sites Rockets go flying start» - so Chief Designer missile defense system (MDS) Georgiyi Kisunko wrote in the book of his poems, donated Burtsev and now also stored in the documentary fund. This book complements the pencil drawing of a polygon with a launcher made G.Kisunko. 
Many of the documents of his personal fund are evidenced by the creation of the family of super-computers "Elbrus".

The works of V.Burtsev dedicated parallelism of computational processes and the development of supercomputer architecture, including multiprocessor computing system "Elbrus" were included in section of fund publications.

Vsevolod Sergeevich Bourtsev awarded the Lenin and State prizes, awarded many orders and medals. He was awarded the Lebedev's prize of the Russian Science Academy for his series of works "Theory and practice of high-performance multiprocessor computers".

\section{Isaak Bruk (1902 - 1974)}

Biography of I.Brook is known from the memoirs of his sister, Mira Brook, the reports and the papers of his colleagues and disciples (Yu.Rogachev, N.Prohorov, A.Zalkind), thier manuscripts and typescripts are stored in the museum.

The museum fund № 213 of corresponding member of the USSR Academy of Sciences I.S. Brook is not the most extensive and there are 45 items of documentary and pictorial materials. Besides the documents related to the creation of electronic computers in our country, it contains not less interesting materials Brook's work in the field of electricity and mechanical devices for the solution of differential and integral equations.

The very interesting photo of Brook on the background of his mechanical integrator, which he had built in 1939, is in his personal fund besides his wonderful portraits and others pictures. Integrator allowed to solve differential equations of order 6 .

The articles of I.Brook "The mechanical device for the approximate solution of differential equations of Laplace-Poisson" (1946), "The unexcited turbo generator asynchronously" (1947) and others, stored in the museum fund, demonstrate his works in the field of electrical engineering and the development of new computing devices.

Prior to digital technology I.Brook engaged in the development of analog computers [3]. In August 1948, together with a young engineer B.Rameev, he presented a project of automatic electronic computer. A little later, the State Committee of the USSR Council of Ministers on the implementation of advanced technology in the national economy gave I.Brook and B.Rameev Copyright Certificate for number 10475 for the invention of the digital computer with a priority date of December 4, 1948, which is also stored in the Polytechnic Museum.

This is the first official document concerning the development of computer technology in the USSR. Professionals in the field of computing technology were not in our country, and I.Brook hired graduates and undergraduates N.Matyuhin, T.Aleksandridi, M.Kartsev. All of them became prominent scientists, computing designers. Isaak Brook photographed surrounded by his colleagues and students on one of the photos stored in his museum fund.

In April 1950 the decree of the Presidium of the USSR Academy of Sciences was issued on the development of electronic digital computing machine M-1 in Electrical laboratory, headed I.Brook, of Energy Institute of the USSR Academy in Moscow. December 15, 1951 Director of the Energy Institute of the USSR Academy 
G.Krzhizhanovskiyi puts his signature on the statement of completion of the establishment of the automatic computer M-1.

Automatic computer M-1 was the first in Russia small digital electronic computer with stored program. The script report for work "Automatic digital computer [M-1]" is stored in personal Brook's fund.

In April 1952 Brook launches new project: designing computer M-2. Nuclear research calculations for Atomic Energy Institute, calculations on the strength of dams constructing Kuibyshev's and Volga's hydroelectric power plants, calculations of thermodynamic and gas dynamic parameters of air for problems related to the launch of missiles were done on this machine.

Almost simultaneously with the construction of the M-2 I.Brook began development of the machine M-3. Based on it, the computer was started in Armenia, Belarus, Hungary and China. The books and the articles on these machines are presented in the Brook's fund.

I.Brook formulated possibilities and principles of controlling machines; their differences from mainframes and put immediate tasks of their application in automatic control in his articles of 1955-1957's.

In 1956 I.Brook made the presentation, which outlined the main directions of industrial applications of computers, at the session of the USSR Academy of Sciences. Two years later the note "Development of the theory, principles of construction and use of specialized and control machines" was prepared under his guidance. These documents were the impetus for the formation a number of research organizations and design offices to control machines and systems in the Soviet Union. In particular, the Institute of Electronic Control Machines of the USSR Academy of Sciences was created. The first director was appointed I.Brook .

The several major events in the history of domestic computer technology related to the name I.Brook:

development the first national automatic digital computer with a stored program M1 in 1951;

conception of small computers for massive engineering and scientific calculations in research institutes and design offices, alternative to the concept of highperformance super-computers;

formulation of a scientific problem "Development of the theory, principles of construction and use of specialized and control machines";

creation of the Engineering School of development and application control machines.

Pioneering works of I.Brook had the strongest influence on the development of computer technology in our country in the 40-60s of the last century.

I.Brook published more than 100 scientific papers. Scientist I.Brook had the talent of the inventor and the experimenter. He received more than 50 invention certificates, 16 of them in the last 5 years of life, when he was already at an advanced age.

The followers and the colleagues I.Brook (B.Rameev, N.Matyuhin, M.Kartsev, G.Lopato, B.Naumov), continuing the tradition of his school, have created themselves teams and scientific schools, played a significant role in the development of domestic 
computing. Also the Institute of Electronic Control Machines continues the tradition of the school I.Brook. Since 2008 it bears his name.

\section{Mikhail Kartsev (1923 - 1983)}

Michael Kartsev, one of the disciples of I.Brook, was born on May 10, 1923 in teachers' family in Kiev [3, 4]. All the Great Patriotic War he fought on the tank and participated in the liberation of Romania, Hungary, Czechoslovakia and Austria. This is evidenced by photos of M.Kartsev in those years, Diploma "Participant of fights for liberation from Nazi invaders ..." and the other fund documents.

After demobilization in 1947 M.Kartsev began to study on the radio department of the Moscow Power Engineering Institute. Being a fifth year student, he began to work in Energy Institute of the USSR Academia of Sciences in the laboratory of electrical systems headed I.Bruk. In this laboratory one of the first Soviet computers - M-1 was created. I.Bruk entrusted development of machine control device - the main program sensor to M.Kartsev.

In 1952, already qualified engineer Kartsev headed the design team of the computer M-2. Works on its creation were conducted as soon as possible from April to December 1952. The photos of the young engineer Mikhail Kartsev are stored in the personal fund of this scientist.

In 1957 M.Kartsev began to work in creating of the computer equipment, focused on the use of early warning systems and missile attack space surveillance. At that time it was the most difficult tasks of the amount of information to be processed, according to the requirements of computing speed, memory and hardware reliability.

In 1958, the special laboratory under the guidance of M.Kartsev was established in the Institute of Electronic Control Machines. It was intended to create the computer M-4 for control and data processing radar space surveillance. M-4 marked a new milestone in the activities M.Kartsev as the chief designer.

M-4 was one of the first computers built by transistors. The RAM cube of M-4 is stored in the museum's collection, photographs of racks with power supply and control panel of the M-4, link rack of Computer M-4 with radar are presented in the personal fund of M.Kartsev. Peripheral processors for parallel computing and eliminate contradictions between the CPU and external devices have been introduced in the M-4 for the first time.

In 1962 the M-4 passed state tests as part of the experimental complex radar and was proposed for serial production.

Original handwriting of Kartsev as the original computer architect clearly manifested in this development. The arithmetic unit was conveying. Operation of results obtain with high (double) precision ensured that extends the use of the computer at various levels of the computer system.

Modified with advanced transistors, this machine was produced serially and called M4-2M. It has performed 220,000 operations per second with high reliability (its mean time to failure was 800-1,000 hours) and was mainly used for the system of missile warning. 
M4-2M computer in many of their characteristics was at the world's best computer technology of the time. Designed in 1965-1966 on the same elements of external devices and external computer M4-3M allowed to combine together dozens of computers M4-2M in a single computer network. The photos of M4-2M, its block diagram are stored in personal fund of Kartsev.

The computing complexes built on the base of M4-2M, provided round the clock operation mode of combat duty. They performed radar information processing securely at all levels of prevention, to ensure the military and political leadership of the country with reliable information about the situation in space.Manufacture of computers M4-2M lasted until 1985, and use - to mid-1990s. Several examples of these computers are in operation at the present moment.

The results of research conducted during the creation of this series formed the basis of M.Kartsev's doctoral dissertation, which he defended in 1965. The USSR State Prize was awarded to him in 1967 for the introduction of M4-2M computers and computer systems in the missile attack warning.

1967 turned out to be significant for Kartsev. Research Institute for Computing Systems was founded on the basis of the development team headed by him of this computer system, and he was appointed director of this institute.

Since 1965 M.Kartsev focused his creative work on the theoretical studies have been aimed at the search for opportunities to improve performance computing facilities. A multiprocessor computer system structure, which can provide simultaneous (parallel) solution of problems of the parts, has a real opportunity to get higher performance at the same level components.

Kartsev showed four kinds of parallelism and defined for each type of possible hardware implementation. Especially large tasks, that usually require high performance computing facilities, have generally a greater or lesser extent all kinds of parallelism. Therefore, multiprocessor computer systems are the most versatile way to create computer systems with the best possible performance. Kartsev's manuscripts and publications of his works kept in the museum indicate to this.

In March 1967 M.Kartsev made the presentation at the symposium in the Siberian Branch of the Academy of Sciences in Novosibirsk, which recounted not only ideas but also many technical solutions for creating a computer system with a capacity of one billion operations per second. It was a bold statement for the time: computers with a capacity of one million operations have not created but here the application sounded a billion! But the depth of study, specific schemes and their interaction convinced of the reality of this complex.

The final stage of Kartsev research questions of multiprocessor computer systems building has been a functional study of the structure of multicomputer complex M-9, submitted to the expert committee in the summer of 1967. Low level of integration of electronic circuits mastered the electronics industry at the time, did not allow realizing this project to life.

Only in 1969, the institute under the leadership of Kartsev could begin to develop one part of the M-9 - vector multiprocessor computer M-10 on the basis of emerging chip (Series 217), and an experimental model was made in August 1971. Such rates of 
development have influenced on the health of chief designer - a massive heart attack put him to bed a few months. But, fortunately, everything ended well.

In September 1973, the first industrial prototype passed a comprehensive review successfully, and production began in December of the same year and continued until the end of the $80 \mathrm{~s}$.

M-10 is a synchronous multiprocessor system with an average capacity of 5 million operations per second and an internal memory of $5 \mathrm{MB}$. It had the ability to carry out parallel processing of data in various formats, to dynamically change the clustering of processors to match the data format.

In 1977 the USSR State Prize was awarded to the team of developers of M-10 and Kartsev was awarded the Order of Lenin.

In 1976-1977, when the domestic electronics industry had mastered the production of integrated circuits, new, more compact memory devices for M-10 have been developed. This allowed more than halve the amount of equipment, size and power consumption of the computer, while maintaining all of its specifications. Machine with the new memory devices called M-10M. Both machines were completely interchangeable and compatible software.

The several units of the M-10 and M-10M components are in museum collection: standard logic block, RAM on ferrite cores, permanent memory unit condenser type on metal punch cards, permanent memory unit of the M-10M on magnetic core with diametric holes and others. The photos of computing complex from 3 M-10 computers, the pictures of the several units of the M-10 are stored in the Kartsev personal fund.

Parallel architecture contribution in productivity was so significant that before $80 \mathrm{~s}$ the computer M-10 was the most powerful computer in the USSR. In terms of performance it exceeded domestic machines (BESM-6 - 4.2 times, the older models of UCS - 5.6 times). Information on the use of M-10, as well as on the previous machine M4-2M was closed to 90s. Only 10 years after the start of development M.Kartsev managed to get permission to publish materials on the M-10 in one of the collections of articles of the Academy of Sciences of the USSR.

In the computer systems of the M-10 computers M.Kartsev proposed and implemented the concept of a fully parallel computing system - with parallelization at all four levels (programs, commands, data and words).

New generation radars required a significant increase in performance computing facilities. In 1979, the institute under the leadership of Kartsev began developing computer fourth generation of the M-13. This supercomputer designed for wide use in processing large amounts of information in real time.

The exposition of the Museum shows the layout of the M-13, which is complemented by the layout of the radar "Darial U-4", also the cell fiber-optic communication line of the M-13 for transmission over fiber optic cable (transmitter-to-board, board-receiver and splitter) is exhibited. The several photos multiprocessor computer M-13 are stored in the Kartsev personal fund.

The heritage of Kartsev is significant and weighty. It created a whole range of them unique computers and systems: M-2, M-4, M4-2M, M-5, M-10, M-13, made significant contributions to computer science. Their practical significance for our 
country is very high. The museum has been carefully preserved inventors' certificates obtained Kartsev on separate devices of his computers and multiprocessor systems.

In 1995 the museum collection of computers was replenished the some blocks of high-performance computers M-series, created under the direct supervision of Mikhail Kartsev, one of the most prominent developers of computers and systems in our country.

In subsequent years, the staff of the Research Institute of computer systems and son Vladimir Kartsev transferred to the museum documentary materials, allowed to form the museum's personal fund № 215 of this outstanding creator.

Now the museum collection of computers and the personal documentary fund constantly replenished with new exhibits thanks to the collaboration with the institute and family of M.Kartsev.

Currently 9 original blocks and units of computers and 1 layout, developed by the ideas of M.Kartsev in the Research Institute of computer systems, are stored and exhibited in the museum. Personal documentary fund of this scientist is 30 items of documentary materials related to his creative and professional activities.

Kartsev's son found his military poems in the family archives. Red Army newspaper "Stalin Banner" with printed Kartsev poem "It is so! ..." and a handwritten version of this poem Vladimir Kartsev gave the Polytechnic Museum.

The series of books written by him was the table as the developers of computers and students of technical universities in related disciplines: "Arithmetic Units of Electronic Digital Computing Machines" (1958), "The Arithmetic of Digital Machines (1969)," Architecture of Digital Computing Machines"(1978), "Computing Systems and Synchronous Arithmetic" (1978).

Kartsev mission was computer science and technology. This brought him happiness and creativity and grief. He devoted all his spare time - at work, at home, on vacation.

M.Kartsev belongs to the category of scientists, whose enormous scientific achievements in life have not been evaluated and officially recognized academic elite.

In 1993 the leadership of the Research Institute of Computing Systems has made the institution name M.Kartsev assignment.

\section{Conclusion}

In 2013 the main building of the Polytechnic Museum was closed for reconstruction. But the museum continues to conduct research on cultural heritage of the peoples of Russia in the field of science and technology. Work in the framework of "Outstanding engineering projects of Russia" and "Engineering Heritage XIX-XX centuries" continues, adding even more personal funds of Russian scientists, inventors and designers.

The updated exposition of the Museum is planned to open in 2018. Most of the materials from personal funds of scientists - founders of the national computer technology will be on display in the exhibition hall of computers, making it the more interesting and meaningfully for visitors. 


\section{References}

1. Lebedev, S.A.: To the 100 anniversary from the birthday of the founder of the national computer technology / Burtsev V. (Responsible Editor), FIZMATLIT, Moscow (2002) СергейАлексеевичЛебедев. К 100-летию со дня рождения основоположника отечественной электронной вычислительной техники / В.С.Бурцев (отв. ред.). М.: ФИЗМАТЛИТ, 2002. 440с.: ил

2. Burtsev, V.: Parallelism of Computational Processes and Development of Supercomputing Architecture. In: Torchigin, V., Nikolskaya, Y., Nikitin, Y. (eds.) TORUSPRESS, Moscow (2006) БурцевВ.С.

ПараллелизмвычислительныхпроцессовиразвитиеархитектурысуперЭВМ:

Сборникстатей / В.П.Торчигин, Ю.Н.Никольская, Ю.В.Никитин (сост.). М.: ТОРУС ПРЕСС, 416 с.: ил (2006)

3. Malinovskiy, В.: History of Computing in Persons. Kiev, (1994) Малиновский Б.Н. История вычислительной техники в лицах. Киев: фирма «КИТ», ПТОО «А.С.К.», 1995. C. 174-197

4. Kartsev, M.A.: Creators of domestic electronics. Issue 3 / Zenin, V., (Author-Composer), Malashevich, B., (Editor), TECHNOSFERA, Moscow (2013)

МихаилАлександровичКарцев. Созидатели отечественной электроники. Вып. 3. / В.Н. Зенин (сост.), Б.М.Малашевич (ред). - М.: ГК Синерджента: Техносфера, 464 с.: ил (2013) 